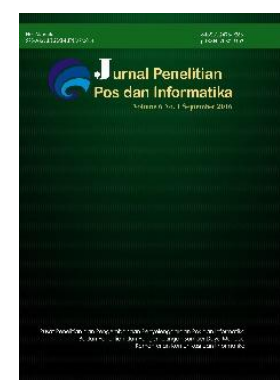

JPPI Vol 5 No 1 (2015) 19 - 36

\author{
Jurnal Penelitian Pos dan Informatika \\ 578/AKRED/P2MI-LIPI/07/2014 \\ e-ISSN: 2476-9266 \\ p-ISSN: 2088-9402
}

DOI: $10.17933 /$ jppi.2015.0501002

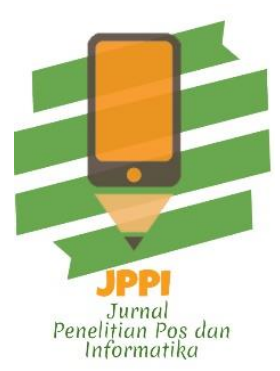

\title{
PENGGABUNGAN, PELEBURAN DAN PENGAMBILALIHAN PADA INDUSTRI TELEKOMUNIKASI DI INDONESIA
}

\section{MERGER, CONSOLIDATION AND ACQUISITION IN THE TELECOMMUNICATION INDUSTRY IN INDONESIA}

\author{
${ }^{1}$ Diah Arum Maharani dan ${ }^{2}$ Helena Wirastri Wulandari \\ ${ }^{1}$ Puslitbang Penyelenggaraan Pos dan Informatika - Kementerian Kominfo \\ Jalan Medan Merdeka Barat No. 9 Jakarta 10110, Indonesia \\ ${ }^{2}$ Faculty of Law, Freie Universitaet Berlin - Jerman \\ ${ }^{1}$ diah003@kominfo.go.id, ${ }^{2}$ helena_wulandari@yahoo.de
}

Naskah diterima : 1 Juni 2015; Direvisi : 29 Juli 2015; Disetujui : 31 Juli 2015

\begin{abstract}
Abstrak
Kajian tentang penggabungan, peleburan dan pengambilalihan dari penyelenggara (operator) telekomunikasi seluler di Indonesia dilakukan untuk lebih menciptakan iklim yang sehat dan membangun perekonomian nasional tanpa merugikan pemain di sektor ini dan juga konsumen. Evaluasi penggabungan, peleburan, dan pengambilalihan dilakukan oleh masing-masing instansi terkait sesuai dengan kewenangan yang diberikan oleh Undang-Undang. Koordinasi tata cara/prosedur penggabungan, peleburan, dan pengambilalihan antara instansi terkait perlu dilakukan. Beberapa hal yang disarankan perlu dilakukan oleh Kemkominfo/BRTI terhadap penggabungan, peleburan, dan pengambilalihan penyelenggara telekomunikasi seluler diantaranya penilaian pre-merger dan pengawasan post-merger. Penilaian premerger melalui nilai perusahaan dan penilaian kelayakan (pre-merger) dalam hal strategic and business due diligence (kecuali isu hukum persaingan usaha); technological \& integration issues; financial \& commercial due diligence (kecuali isu hukum perusahaan); dan public interest. Sementara itu, pengawasan post-merger meliputi: laporan berkala tentang pencapaian komitmen, laporan berkala tentang kinerja, dan pengawasan terhadap kewajiban interkoneksi.
\end{abstract}

Kata Kunci : penggabungan, peleburan dan pengambilalihan;pre-merger, post-merger

\section{Abstract}

Studies on merger, consolidation and acquisition of mobile telecommunications providers(operators) in Indonesia is to be carried out to further create a healthy climate, and build the national economy, which would not be detrimental to the players and consumers in the sector. The evaluation of merger, consolidation, and acquisitions were carried out by each of the relevant agencies in accordance with the authority granted by the Act. The coordination of the procedure / merger procedure, consolidation or acquisition between the relevant agencies is to be implemented. Based on this study Kemkominfo / BRTI is recommended to assess the pre-merger and supervision of post-merger through the company's value and feasibility assessment (pre-merger) in terms of strategic and business due diligence (except in the law concerning competitive issues); technological and integration issues; financial \& commercial due diligence (except for the company's legal issues); and public interest. The post-merger includes: periodic reports on the achievement of commitments, periodical reports on the performance and supervision of interconnection obligations.

Keywords: merger, acquisition and consolidation, pre-merger, post-merger 


\section{PENDAHULUAN}

Industri telekomunikasi merupakan salah satu industri yang menjanjikan profit besar bagi investornya, apalagi dengan jumlah penduduk yang banyak tentunya akan menjadi pasar yang baik bagi investor di bidang ini. Kondisi ini juga menjadi pertimbangan bagi pelaku bisnis telekomunikasi untuk melakukan investasi di Indonesia. Luas wilayah Indonesia dan jumlah penduduk Indonesia yang besar menjadikan Indonesia sebagai pasar yang baik bagi industri telekomunikasi. Perkembangan industri telekomunikasi di Indonesia ditandai dengan jumlah pelaku usaha maupun pelanggan layanan telekomunikasi yang meningkat.

Sampai dengan akhir Desember 2012, terdapat sebanyak 125 izin sebagai penyelenggara jaringan telekomunikasi di Indonesia. Penyelenggaraan telekomunikasi ini meliputi penyelenggaraan jaringan telekomunikasi, jasa telekomunikasi, penyelenggaraan telekomunikasi khusus. Peningkatan terbanyak terdapat pada penyelenggara jaringan tetap dengan peningkatan sebesar $12,63 \%$ pada tahun 2012. Sementara untuk penyelenggara jaringan bergerak mengalami peningkatan juga sebesar 5,88\% pada tahun 2012 . Sementara, jumlah pelanggan seluler di Indonesia hingga tahun 2011 mencapai 249,80 juta pelanggan atau terjadi peningkatan sekitar $18,23 \%$ dari tahun sebelumnya. Peningkatan juga terjadi pada tahun 2012 sebesar 12,87\% dengan jumlah pelanggan pada tahun 2012 mencapai 281 juta pelanggan (Kementerian Komunikasi dan Informatika, 2013). Perkembangan dalam bidang telekomunikasi khususnya seluler baik dari sisi perangkat telepon maupun penyelenggaraan jaringan bergerak seluler sangat terlihat dari perkembangan jumlah pelanggan jaringan tersebut. Pesatnya pertumbuhan pelanggan seluler menunjukkan tingginya kebutuhan masyarakat terhadap layanan komunikasi seluler di Indonesia.

Walaupun menjadi pasar yang menjanjikan, pasar telekomunikasi Indonesia dipenuhi dengan tantangan-tantangan bagi operator seluler. Tantangan ini diantaranya disebabkan oleh banyaknya operator seluler yang beroperasi yang membuat jumlah pemain banyak, sehingga akan sangat kompetitif. Jumlah pemain operator seluler di Indonesia saat ini cukup banyak, dengan regulasi yang ketat, melalui pemberian ijin per jenis layanan. Selain itu, kenaikan jumlah pelanggan di industri ini tidak diikuti dengan peningkatan pendapatan mengikuti pertambahan jumlah penggunanya, operator tidak dapat mengandalkan pendapatan dari voice dan SMS saja tetapi juga harus dapat bertransformasi dalam memberikan layanan data.

Kedepannya dalam memenuhi kebutuhan layanan data tentunya akan meningkatkan kebutuhan bandwidth yang semakin besar bagi operator seluler, hal ini belum lagi ditambah dengan transformasi penyelenggara BWA yang akan menjadi penyelenggara seluler tentunya semakin memperbanyak operator. Di tengah ketatnya persaingan saat ini, operator yang ingin berhasil haruslah mempunyai gambaran seperti apa industri telekomunikasi seluler Indonesia di masa depan. Operator yang dapat memprediksi masa depan dunia telekomunikasi akan dapat mempersiapkan strategi yang tepat untuk mengatasinya.

Penggabungan, peleburan dan pengambilalihan telah menjadi strategi andalan industri telekomunikasi selama bertahun-tahun. Selama dekade terakhir industri telekomunikasi 
telah menghabiskan USD 1,5 triliun untuk kegiatan penggabungan, peleburan dan pengambilalihan (Jean-Christophe Lebraud, 2012). Strategi investasi ini mengubah lanskap industri menjadi lebih kompetitif. Namun, motivasi dibalik terjadinya penggabungan, peleburan dan pengambilalihan didorong oleh terjadinya persaingan dan gangguan pada industri telekomunikasi. Perubahan struktur kepemilikan operator telekomunikasi di Indonesia melalui perpindahan penguasaan saham mayoritas juga pernah terjadi di Indonesia, contohnya penggabungan PT. Indosat, PT. Satelindo, PT. IM3, dan PT. Bimagraha (Puslitbang SDPPI, 2013). Penggabungan ini menyebabkan Indosat menguasai frekuensi GSM900 dan DCS1800 yang dimiliki oleh Satelindo. Perubahan struktur kepemilikan melalui saham juga otomatis memindahkan kepemilikan seluruh aset perusahaan termasuk spektrum frekuensi kepada pemilik saham yang baru. Perubahan struktur kepemilikan saham terjadi pada hampir seluruh operator di Indonesia, termasuk operator besar seperti Telkomsel, Indosat, XL-Axiata, Mobile-8 dan lain-lain.

Di sisi lain, berdasarkan Undang-Undang No. 36 Tahun 1999, dalam penyelenggaraan telekomunikasi dilarang melakukan kegiatan yang dapat mengakibatkan terjadinya praktik monopoli dan persaingan usaha tidak sehat diantara penyelenggara telekomunikasi. Untuk menciptakan kondisi yang sehat bagi seluruh pemain di industri telekomunikasi, perlu dilakukan penelitian mengenai penggabungan, peleburan dan pengambilalihan dari sektor telekomunikasi Indonesia sehingga tercipta iklim yang sehat dan membangun perekonomian nasional yang tidak merugikan pemain di sektor ini dan juga konsumen.

\section{METODE}

Penelitian ini menggunakan pendekatan kualitatif dengan melakukan analisis deskriptif terhadap data kualitatif dan kuantitatif. Penelitian ini juga menggunakan pendekatan normatif analisis dengan fokus penelitian pada pengembangan hukum sektor industri penyelenggaraan telekomunikasi seluler, khususnya mengenai penggabungan, peleburan, dan pengambilalihan.

Penelitian diawali dengan melakukan identifikasi masalah terkait penggabungan, peleburan dan pengambilalihan dalam industri telekomunikasi seluler. Selanjutnya dilakukan pemetaan penyelenggaraan telekomunikasi seluler yang menggambarkan kondisi industri telekomunikasi seluler, penjelasan mengenai struktur pasar, perilaku penyelenggara telekomunikasi seluler, dan performa industri telekomunikasi seluler.

Untuk pemetaan tersebut diperlukan data mengenai jumlah penyelenggara telekomunikasi seluler termasuk dengan kepemilikan ijin, baik sebagai penyelenggara jaringan dan/atau jasa, maupun pangsa pasar masing-masing penyelenggara. Data tentang teknologi telekomunikasi seluler dan kepemilikannya serta perilaku penyelenggara telekomunikasi seluler juga akan diidentifikasi. Perilaku yang dimaksudkan disini meliputi perilaku yang berkaitan dengan penyediaan interkoneksi, tarif, dan perilaku lainnya yang relevan dengan penyelenggaraan telekomunikasi seluler yang sehat. 
Data lain yang diperlukan untuk penyelenggaraan telekomunikasi seluler di menggambarkan kondisi industri telekomunikasi Indonesia.

seluler adalah data-data mengenai kinerja penyelenggaraan telekomunikasi seluler, yaitu datadata yang berkaitan dengan kualitas layanan, tarif, ketersediaan alternatif layanan bagi konsumen, dan data-data kualitatif lainnya yang berkaitan dengan kepuasan pelanggan atau konsumen telekomunikasi seluler.

Berdasarkan data dan hasil analisis maka akan disusun rekomendasi mengenai kebijakan dan aturan-aturan tentang penggabungan, peleburan dan

\section{HASIL DAN PEMBAHASAN}

\section{Kondisi Industri Seluler Saat Ini \\ Berdasarkan data Information and}

Communication Technology (ICT) mengenai kesiapan jaringan yang dimiliki oleh Indonesia masih berada dalam urutan kempat dibawah beberapa Negara ASEAN lainnya dalam Network Readiness Index (NRI). (Sutjipto, 2014). pengambilalihan sebagai solusi dari permasalahan

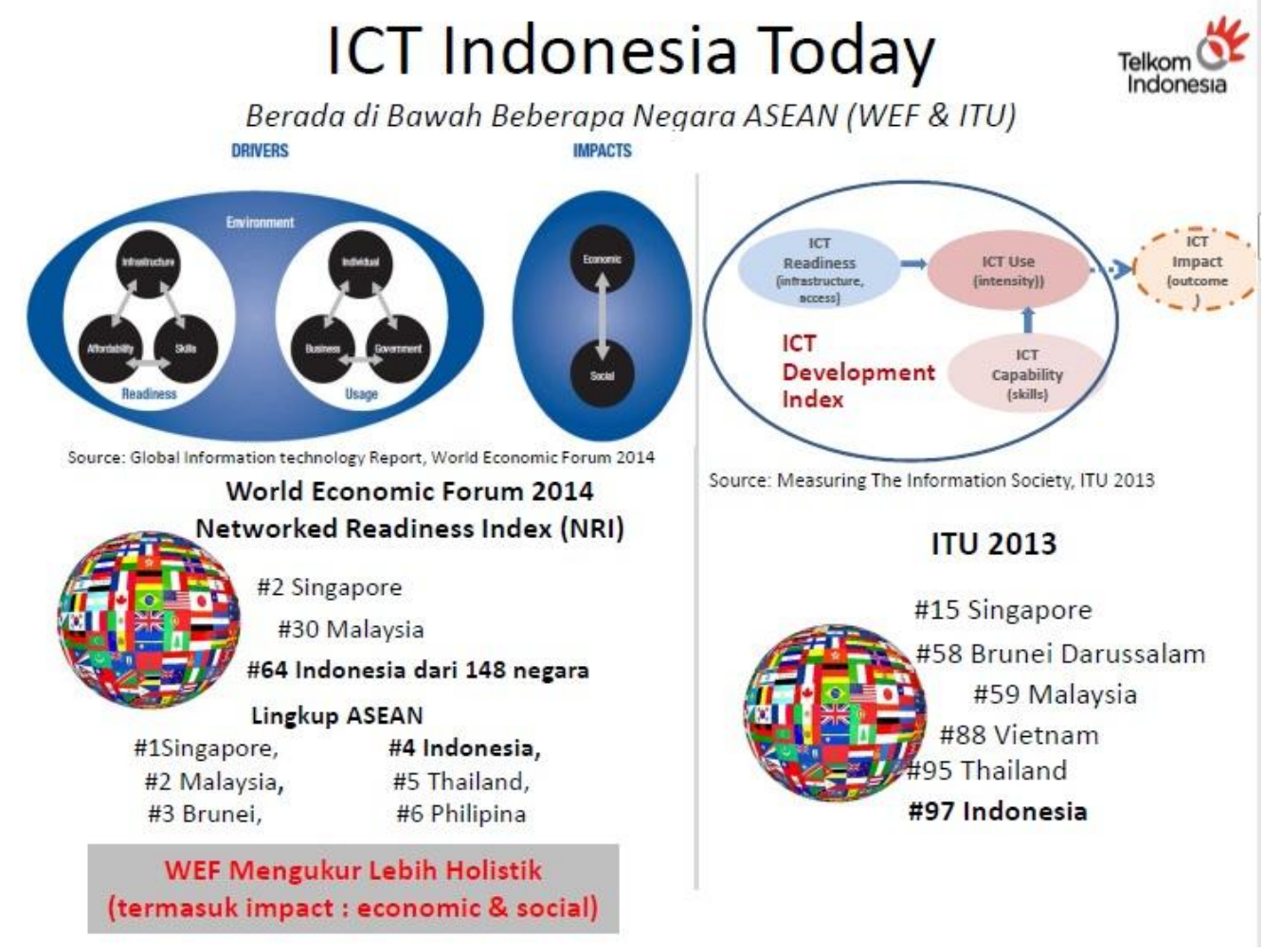

Gambar 1. ICT Indonesia Today (WEF \& ITU)

Sumber: Presentasi Telkom pada Seminar Kominfo di Makasar, November 2014

Dalam gambar tersebut dapat dilihat bahwa kesiapan jaringan Indonesia masih berada dibawah Singapura, Malaysia dan Brunei. Oleh karena itu perlu ada upaya peningkatan NRI jaringan Indonesia dalam meningkatkan kesiapan Indonesia menghadapi persaingan dengan negara lain. Mengacu pada gambar 1, dapat disimpulkan bahwa jaringan yang dimiliki oleh Indonesia masih belum mencukupi untuk menghadapi persaingan kedepan. Sedangkan jaringan yang ada saat ini dikuasai oleh 
Telkomsel (peringkat 1), XL (peringkat 2) dan Indosat (peringkat 3).

Dalam menentukan struktur pasar, salah satu komponen penting yang harus diketahui adalah pangsa pasar dari para pelaku usaha. Berikut ini adalah data-data yang digunakan untuk melihat pangsa pasar dari masing-masing pelaku usaha telekomunikasi seluler.

Berdasarkan tabel 1, maka pangsa pasar berdasarkan total produksi data pada Tahun 2012 dikuasai oleh PT. SmartFren Telecom, , yaitu sebesar 33\%. Penguasaan pangsa pasar kedua terbesar dipegang oleh PT. Telekomunikasi Selular, yaitu sebesar 31\%. Penguasaan ketiga terbesar dimiliki oleh PT. XL Axiata, dengan pangsa pasar sebesar 14\%. Sedangkan PT. Indosat, berada pada peringkat keempat dengan pangsa pasar sebesar 9\%.

Tabel 1. Pangsa Pasar Berdasarkan Total Produksi Data

\begin{tabular}{|c|c|c|c|c|c|c|}
\hline \multirow[b]{2}{*}{ No. } & \multirow[b]{2}{*}{ Perusahaan } & \multicolumn{2}{|c|}{2011} & \multicolumn{2}{|c|}{2012} & \multirow{2}{*}{$\begin{array}{c}\text { VS. } 2011 \\
\text { GROWTH }\end{array}$} \\
\hline & & $\begin{array}{c}\text { Total } \\
\text { Produksi } \\
\text { Data } \\
\text { (Terrabyte) }\end{array}$ & $\begin{array}{l}\text { Market } \\
\text { Share }\end{array}$ & $\begin{array}{c}\text { Total } \\
\text { Produksi } \\
\text { Data } \\
\text { (Terrabyte) } \\
\end{array}$ & $\begin{array}{l}\text { Market } \\
\text { Share }\end{array}$ & \\
\hline 1 & PT Telekomunikasi Selular & - & $0 \%$ & 51,938 & $31 \%$ & \\
\hline 2 & PT Indosat & 9,671 & $23 \%$ & 15,194 & $9 \%$ & $57.1 \%$ \\
\hline 3 & PT XL Axiata & 10,858 & $25 \%$ & 22,612 & $14 \%$ & $108.3 \%$ \\
\hline 4 & PT Hutchison CP Telecom & & $0 \%$ & 5,130 & $3 \%$ & \\
\hline 5 & PT Telekomunikasi Indonesia & 5,247 & $12 \%$ & 9,421 & $6 \%$ & $79.6 \%$ \\
\hline 6 & PT Axis Telekom Indonesia & 2,920 & $7 \%$ & & $0 \%$ & \\
\hline 7 & PT Bakrie Telekom & & $0 \%$ & 6,970 & $4 \%$ & \\
\hline 8 & PT Smartfren Telecom & 13,979 & $33 \%$ & 54,234 & $33 \%$ & $287.97 \%$ \\
\hline & Total & 42,675 & $100 \%$ & 165,499 & $100 \%$ & $287.81 \%$ \\
\hline
\end{tabular}

Sumber: Direktorat Telekomunikasi, Ditjend PPI

Sementara itu, pada Tabel 2, pangsa pasar berdasarkan jumlah pelanggan broadband dikuasai oleh PT. Telekomunikasi Indonesia dengan pangsa pasar sebesar $88,87 \%$. Kemudian penguasaan pangsa pasar terbesar kedua dimiliki oleh PT. Indosat dengan pangsa pasar sebesar 5,44\%. Pada posisi ketiga terbesar adalah PT. Bakrie Telecom (BTEL) dengan penguasaan pangsa pasar sebesar $3,57 \%$.

Selanjutnya, berdasarkan data dari Ditjen PPI, kondisi pasar mobile saat ini sudah jenuh. Jumlah penyelenggara yang relatif banyak dan churn yang tinggi mengakibatkan terjadi perang harga. Akibat adanya perang harga tersebut membuat kualitas produk maupun layanan juga mengalami penurunan. Ketersediaan layanan dapat digambarkan bahwa availability rendah, dan distribusi cakupan ke arena sub urban dan rural hanya dilakukan oleh satu pelaku penyelenggara.

Dari sisi penyelenggara, pertumbuhan EBITDA masih terjadi, namun pertumbuhannya mulai menurun, bahkan EBITDA negatif terjadi pada penyelenggara yang tidak dominan. Pada Tahun 2012 terjadi rugi bersih, baik pada penyelenggara dominan maupun penyelenggara non dominan. 
Tabel 2. Pangsa Pasar Berdasarkan Jumlah Pelanggan Broadband

\begin{tabular}{|c|c|c|c|}
\hline \multirow[b]{2}{*}{ No. } & \multirow[b]{2}{*}{ Perusahaan } & \multicolumn{2}{|l|}{2012} \\
\hline & & $\begin{array}{c}\text { Total Produksi } \\
\text { Data } \\
\text { (Terrabyte) } \\
\end{array}$ & $\begin{array}{l}\text { Market } \\
\text { Share }\end{array}$ \\
\hline 1 & PT NTT Indonesia & 832 & $0.01 \%$ \\
\hline 2 & PT Indosat & 828,310 & $5.44 \%$ \\
\hline 3 & PT XL Axiata & 503 & $0.00 \%$ \\
\hline 4 & PT Telekomunikasi Indonesia & $135,293,69$ & $88.87 \%$ \\
\hline 5 & PT First Media & 290,000 & $1.90 \%$ \\
\hline 6 & PT Centrin & 9,521 & $0.06 \%$ \\
\hline 7 & PT AT\&T & 269 & $0.00 \%$ \\
\hline 8 & BTEL & 543,956 & $3.57 \%$ \\
\hline 9 & PT Palapa Pacific (ITKP) & & $0.00 \%$ \\
\hline 10 & PT Atlasat ITKP & 361 & $0.00 \%$ \\
\hline & Total & $152,246,12$ & $\begin{array}{l}100 . \\
00 \%\end{array}$ \\
\hline
\end{tabular}

Sumber: Direktorat Telekomunikasi, Ditjend PPI

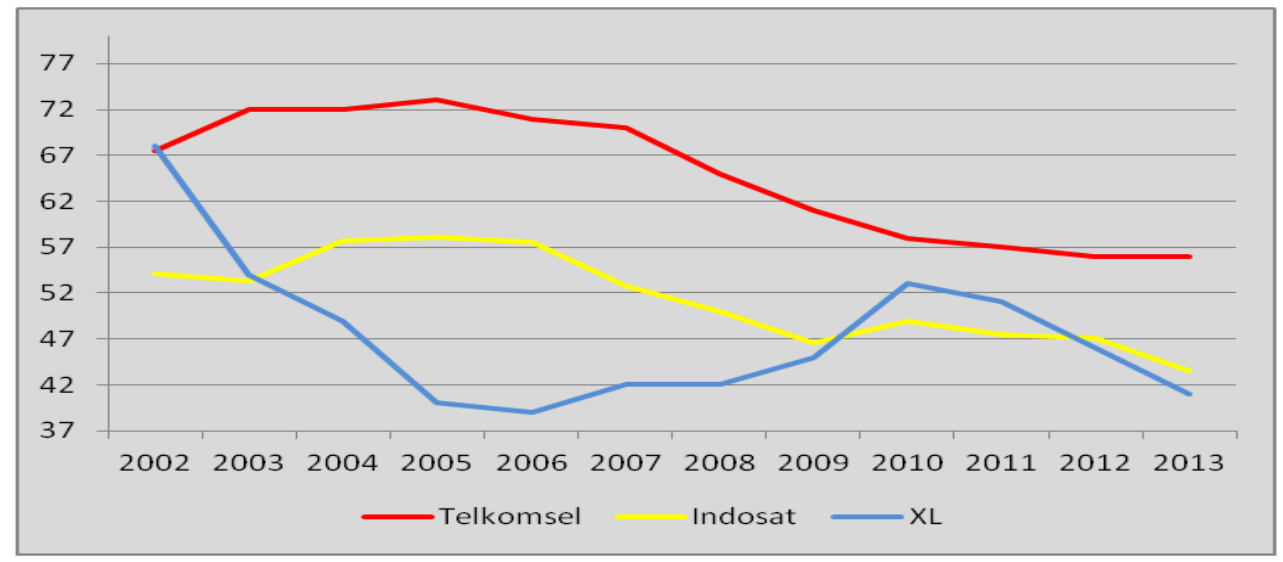

Gambar 2. Perbandingan Profitabilitas 3 Operator berdasarkan Return on Asset (\%) Sumber: BRTI

Kondisi tersebut diatas dapat dilihat dari hasil penelitian dan analisis pasar yang dilakukan oleh Ditjend PPI, yang menunjukkan bahwa pertumbuhan kinerja industri seluler semakin melandai. Hasil penelitian dan analisis pasar tersebut memperlihatkan bahwa:

1. Revenue industry seluler hanya ditopang oleh 2 (dua) penyelenggara, sementara EBITDA margin penyelenggara lainnya negative
2. Tingkat churn diperkirakan sudah berada pada level 22\%;

3. Biaya akuisisi pelanggan cukup mahal dan biaya entry to market semakin tinggi;

4. Dinamika indikator ekonomi terjadi pada penyelenggara non dominan;

5. Satu penyelenggara mendorong skala ekonomi yang besar bagi pelaku usaha non dominan.

Sedangkan untuk kondisi pasar broadband, berdasarkan data Direktorat Telekomunikasi, 
Ditjend PPI, kondisi pasar broadband dapat digambarkan bahwa:

1. Pasar masih dikuasai oleh PT. Telkom, dengan pertumbuhan yang rendah;

2. Pertumbuhan yang rendah tersebut terjadi sebagai akibat pasar mobile broadband belum terbentuk sebagai basis dalam mendorong pengembangan fixed broadband;

3. Biaya infrastruktur yang tinggi dan ketidakterbukaan akses bagi gedung dan kawasan menjadi faktor hambatan yang utama;

4. Suplai pasar secara marjinal masih terjadi oleh pelaku usaha yang pragmatis dalam memenuhi demand broadband.

2. Penggabungan, Peleburan Dan Pengambilalihan Yang Telah Terjadi Di Industri Seluler

Indosat, Satelindo, dan IM3

Merger Indosat, Indosat Multi Media Mobile (IM3) dan Satelindo terjadi pada Tahun 2003. Bentuk merger tersebut adalah merger vertikal, dimana Indosat menggabungkan anak perusahaannya yang bergerak dalam industri seluler, yaitu IM3 dan Satelindo dengan Indosat. Tujuan penggabungan adalah untuk menjadikan Indosat sebagai penyelenggara jaringan dan jasa terpadu yang berfokus pada selular. Melalui merger tersebut, IM3 dan Satelindo tidak hanya akan menjadi satu manajemen dan keputusan finansial yang terpadu, melainkan juga jaringan yang terpadu dan sistem manajemen brand yang terpusat. Melalui cara ini Indosat ingin mencapai sinergi yang maksimal dalam hal pengeluaran modal, menghindari duplikasi biaya dan menghilangkan persaingan dalam pencarian pendanaan antara Satelindo dan IM3.

\section{Akuisisi Mobile 8 dan Smart}

Akuisisi antara Mobile 8 dan Smart dilaksanakan pada Tahun 2010 melahirkan Smartfren. Akuisisi tersebut ditujukan untuk mencapai skala ekonomis yang ideal, karena melalui akuisisi dimungkinkan adanya pengaturan pengeluaran operasional yang lebih efisien dan efektif sehingga dapat mencapai penghematan biaya operasional bagi kedua perusahaan. Dengan demikian, melalui upaya akuisisi tersebut dapat memperkuat posisi layanan di pasar telekomunikasi nasional.

Akuisisi saham Axis oleh XL

Akuisisi saham Axis oleh XL dilakukan pada Tahun 2014. Terdapat beberapa manfaat dari akuisisi Axis dan XL yang dikemukaan. Manfaat tersebut antara lain adalah merealisasikan program broadband nasional sehingga dapat ikut mendorong program pemerintah memperkuat industri telekomunikasi, mendorong peningkatan Pendapatan Negara Bukan Pajak (PNBP) dari sektor telekomunikasi. Disamping itu, dengan dilaksanakannya akuisisi tersebut maka akan dapat meningkatkan kualitas layanan dan jaringan menjadi lebih baik, serta meningkatkan ketersediaan produk dan layanan customer service di pasar.

\section{Roadmap Industri Seluler Indonesia Masa Depan}

Trend industri telekomunikasi nantinya akan terdapat banyak perubahan landscape. Hal tersebut disebabkan karena adanya berbagai perkembangan, yaitu perkembangan teknologi, konvergensi telekomunikasi, penyiaran dan 
komputer, kebutuhan bandwidth yang besar ke arah pita lebar, dan teknologi netral yang membutuhkan spectrum refarming. (Sutadi, 2014)

Saat ini sudah mulai dapat dilihat adanya pergeseran industri dari voice dan SMS ke data. Disamping itu juga penggunaan broadband semakin meningkat. Oleh karena itu, peran data dan broadband di masa depan akan semakin penting. Namun sayangnya, meskipun terdapat trafik data yang terus meningkat, namun terjadi penurunan pemasukan operator, seperti yang ditunjukkan oleh gambar 3.

Sedangkan pada Trend Konvergensi
Industri Telekomunikasi kedepannya adalah seperti yang digambarkan pada gambar 4, dimana industri telekomunikasi akan berkembang membentuk suatu pasar yang saling terhubung antara telekomunikasi, penyiaran dan komputer.

Sejalan dengan perkembangan industri ke depan, maka diperlukan regulasi yang mendukung broadband. UU No. 36/1999 dan PP 53/2000 yang berlaku saat ini sudah tidak sesuai dengan perkembangan industri TIK yang dinamis. Selain itu, untuk menumbuhkan konten dibutuhkan konsep intermediary sebagai platform yang terbuka bagi industri.

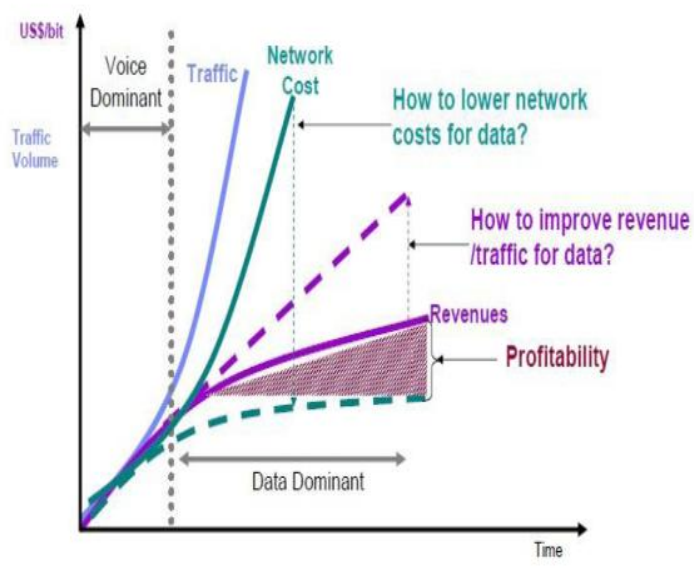

\section{Scissor Effect}

Gambar 3. Scissor Effect

Sumber: Nokia-Siemens; IBM Institute for Business Value (IBV) Analysis

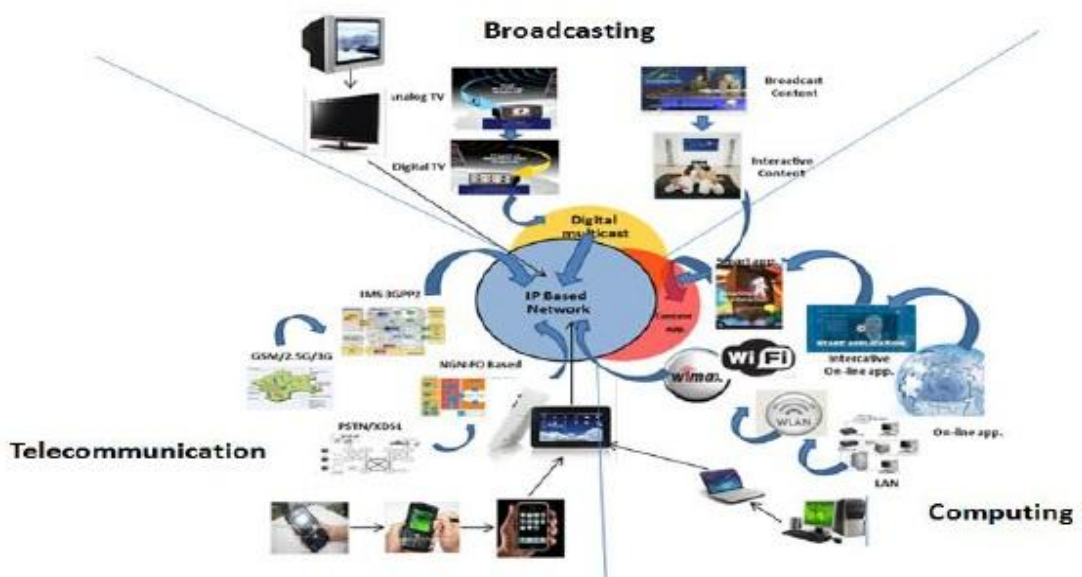

Gambar 4. Trend Konvergensi Telekomunikasi

Sumber: Direktorat Telekomunikasi - Ditjend PPI 


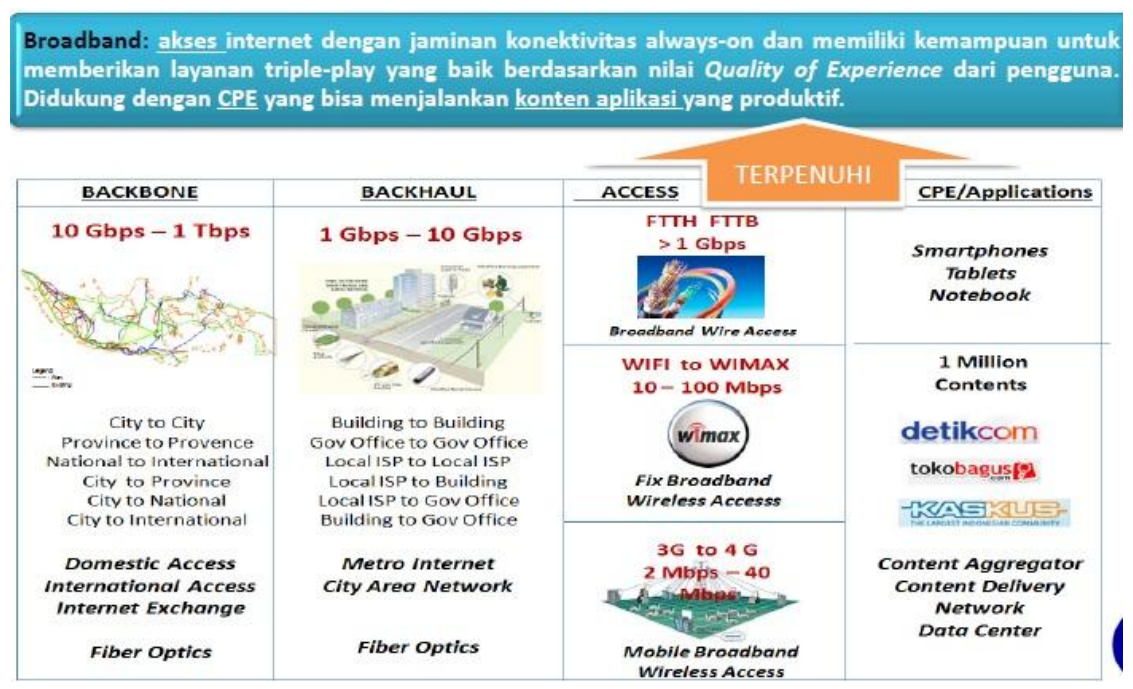

Gambar 5. Kriteria Broadband

Sumber Direktorat Telekomunikasi, Ditjend PPI

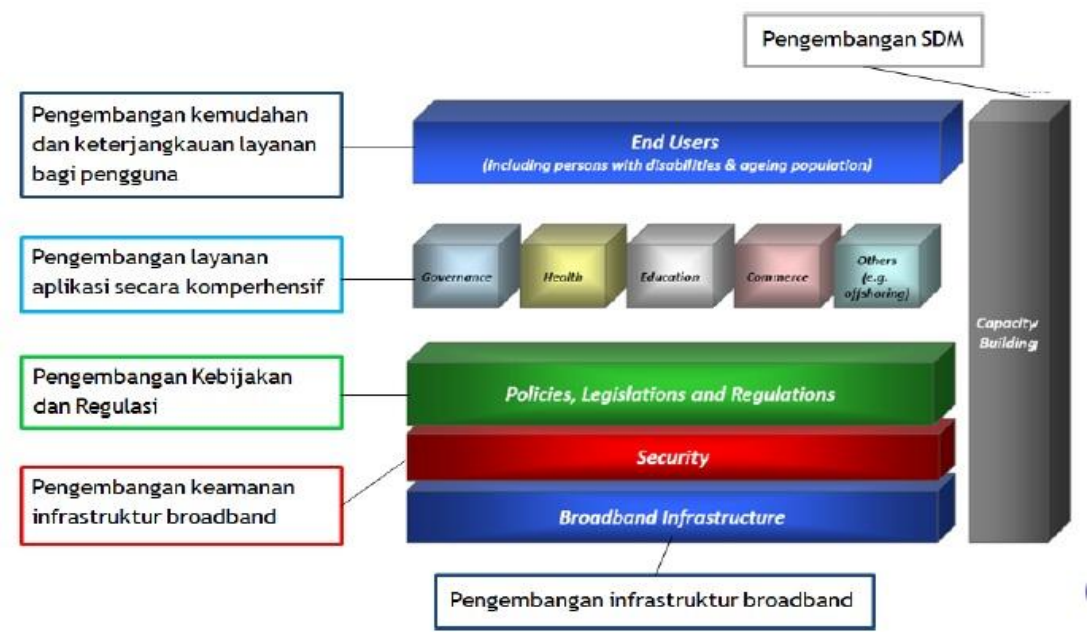

Gambar 6. Ekosistem Broadband

Sumber: Direktorat Telekomunikasi, Ditjend PPI

Masing-masing aspek tersebut memerlukan capacity building bagi SDM-nya. Namun, dalam pengembangan broadband, terdapat berbagai permasalahan yang terkait dengan backbone, backhaul, access, dan content, sebagaimana dapat dilihat pada gambar 7 .

Ada 4 (empat) masalah utama, yaitu infrastruktur dan kebijakan yang belum mendukung broadband, keamanan infrastruktur belum dijamin, belum adanya kesamaan misi antar sektor, dan masalah efisiensi industri telekomunikasi.
Pemerintah juga telah menyiapkan Strategic Development Plan (SDP) Industri Telekomunikasi. SDP yang meliputi rencana pergerakan perubahan struktur beserta komposisinya, rencana roadmap regulasi penyelenggaraan telekomunikasi sebagai tools dalam mencapai target rencana pergerakan perubahan struktur industri beserta komposisinya, dan rencana roadmap kebijakan sebagai fasilitasi rencana pergerakan perubahan struktur industri beserta komposisinya. 

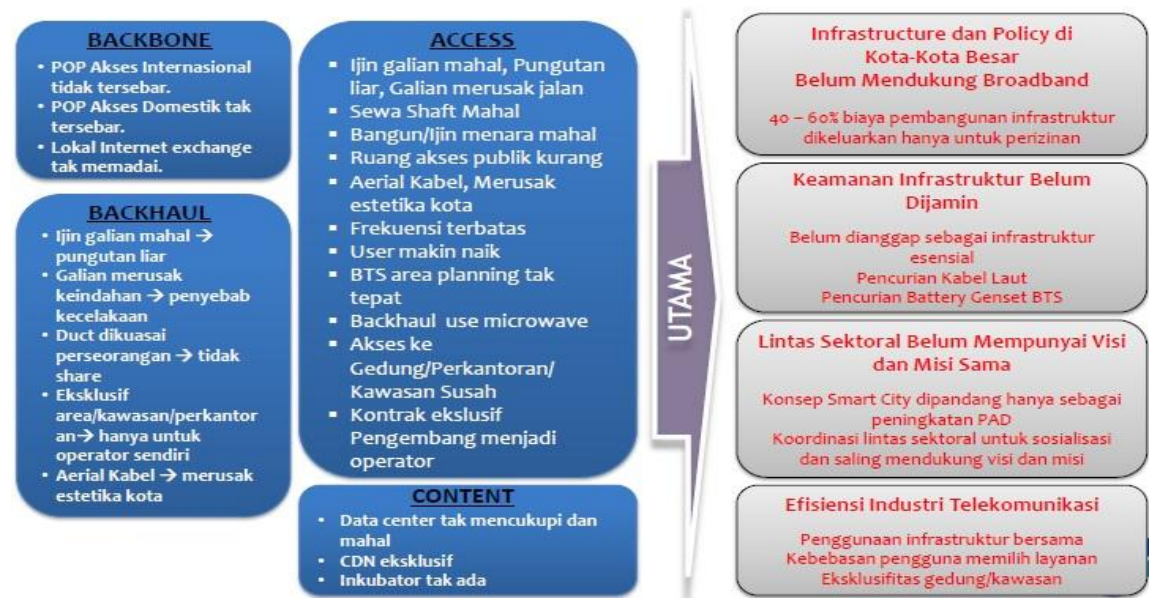

Gambar 7. Permasalahan Pengembangan Broadband

Sumber: Direktorat Telekomunikasi, Ditjend. PPI

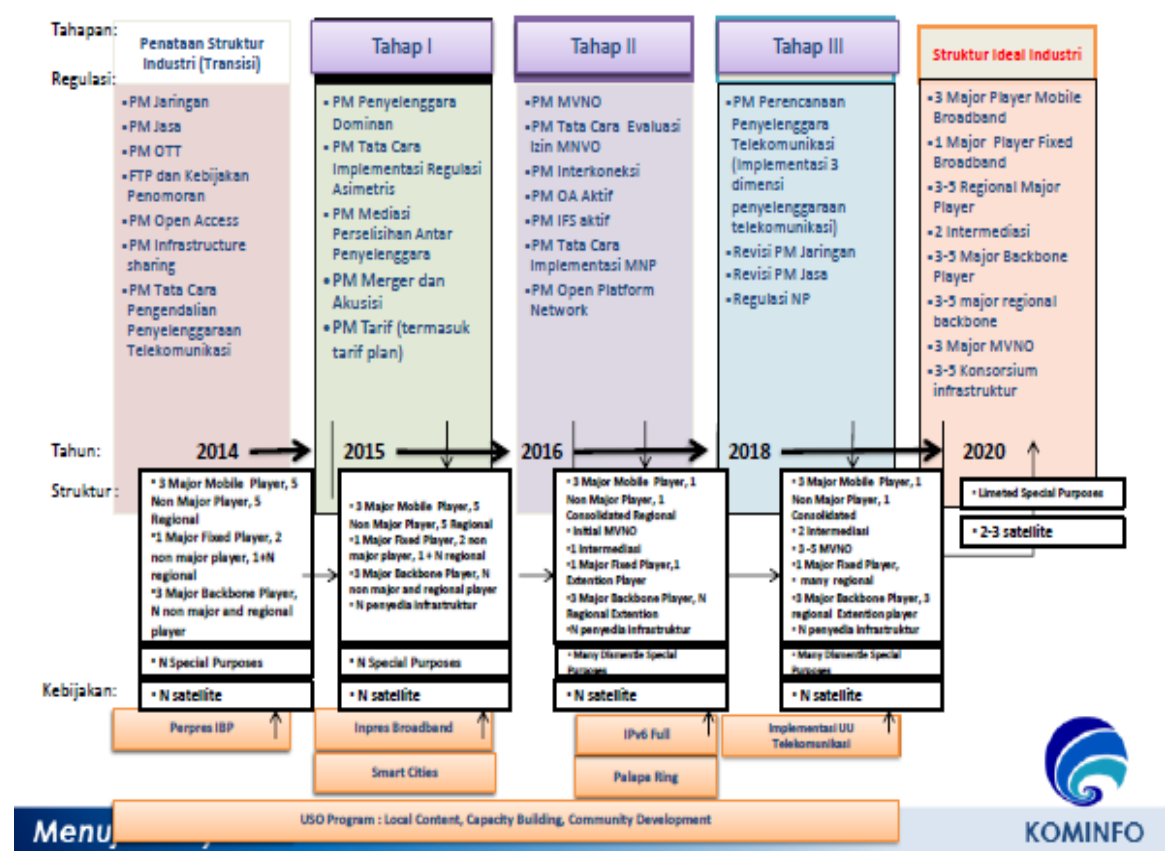

Gambar 8. Strategic Development Plan Industri Telekomunikasi

Sumber: Direktorat Telekomunikasi, Ditjend PPI

Berdasarkan data Direktorat

Telekomunikasi, Ditjend PPI, terdapat beberapa hal yang perlu dipertimbangkan dalam konsep strategi, yaitu:

- "Spektrum frekuensi“ yang ditempatkan sebagai "company value" membuat reposisi konsolidasi secara B2B sulit tercapai,

- Implementasi fleksibilitas penggunaan spektrum frekuensi masih menunggu perubahan
PP 53 (atau menunggu UU Telekomunikasi baru),

- Implementasi UU Telekomunikasi baru kemungkinan baru akan dilaksanakan pada Tahun 2018,

- Diperlukan adanya roadmap regulasi dan kebijakan yang mendorong reposisi tahapan konsolidasi industri oleh pasar, 
- Penyelenggara yang menyuplai pasar secara marjinal dengan hanya menyuplai demand tertentu perlu dikonsolidasi agar terdapat kepastian pasar bagi penyelenggara untuk mengakselerasi pertumbuhan broadband,

- Penyelenggara telekomunikasi khusus masih "enggan" menggunakan layanan yang disediakan oleh industri,

- Adanya keterbukaan industri penyiaran pada saat broadband (baik sebagian maupun keseluruhan) menjadi "single access" bagi masyarakat,

- Implementasi layanan konvergensi (ecommerce, e-logistic, e-transaction dan lainlain) belum efektif,

- Konsistensi implementasi roadmap kominfo harus tetap dijaga,

- Realisasi pencapaian target RPJM KOMINFO,

- Perlu ada pendekatan soft approach yang mendorong industri bergerak secara bertahap menuju ekosistem yang ideal (struktur dan komposisi ideal),

- Pendekatan soft approach akan diganti pada pendekatan hard approach yang memaksa industri bertransformasi ke ekosistem yang ideal setelah dianggap siap.

- Adanya suatu pergerakan industri yang difasilitasi implementsi kebijakan dan regulasi yang konsisten dan transparan bagi pelaku usaha industri.

Pemerintah telah menyiapkan berbagai strategi untuk mencapai pasar seluler dan broadband yang sehat. Strategi tersebut telah disusun dengan rinci yang mencakup berbagai isu penting, seperti teknologi, jumlah pelaku usaha (struktur pasar), perizinan, peran pemerintah. Strategi tersebut dimaksudkan untuk menghasilkan kinerja industri telekomunikasi yang lebih baik di masa depan. Perbaikan kinerja industri telekomunikasi di masa depan akan terlihat dari adanya pertumbuhan ketersediaan jaringan dan layanan telekomunikasi bagi pengguna, baik dari sisi kualitas dan kuantitas.

\section{Potensi Penggabungan, Peleburan Dan Pengambilalihan Di Masa Depan}

Berbagai pendapat mengemukakan bahwa penggabungan, peleburan dan pengambilalihan sangat diperlukan untuk mencapai industri telekomunikasi seluler yang lebih baik. Penggabungan, peleburan dan pengambilalihan adalah cara untuk mencapai berbagai target strategi yang telah disusun.

Dalam FGD I disinggung bahwa penggabungan, peleburan, dan pengambilalihan diperlukan dengan beberapa alasan berikut ini (Sutadi, 2014):

- Perkembangan teknologi yang cepat dan harus diikuti membutuhkan CAPEX dan OPEX yang besar;

- Persaingan untuk dapat memberikan layanan broadband membutuhkan spektrum frekuensi besar sehingga menjadi daya pemikat operator untuk melakukan konsolidasi;

- Konsolidasi dapat juga terjadi dan dibangun akibat adanya operator yang sudah "menyerah" maupun agar dapat maju bersama melalui pemanfaatan infrastruktur secara bersama;

- Selain Penggabungan, peleburan, dan pengambilalihan tidak hanya dapat dilakukan secara horisontal, tetapi juga secara vertikal.

Pada prinsipnya, inisiasi penggabungan, peleburan dan pengambilalihan sepenuhnya berasal 
dari industri sebagai upaya untuk mencapai efisiensi yang lebih baik dan alasan bisnis lainnya. Namun demikian, regulator dapat mendorong penggabungan, peleburan, dan pengambilalihan yang dipandang sebagai solusi terhadap aturan prerequisite dalam penyelenggaraan telekomunikasi.

Dalam hal regulator mendorong adanya penggabungan, peleburan dan pengambilalihan, regulator akan bertindak sebagai booster dan enabler. Regulator sebagai booster penggabungan, peleburan dan pengambilalihan dengan mengatur batasan regulasi yang dibuat dalam penyelenggaraan. Sedangkan regulator sebagai enabler mengatur regulasi penggabungan, peleburan, pegambilalihan yang dibuat.

Apabila melihat kondisi industri telekomunikasi saat ini, maka dapat dikatakan bahwa terdapat potensi adanya penggabungan, peleburan, pengambilalihan di masa depan cukup besar. Hal tersebut karena didorong oleh pertimbangan manfaat bagi pelaku bisnis itu sendiri dan kepentingan regulator untuk mengatur industri telekomunikasi dengan lebih baik

\section{Manfaat Penggabungan, Peleburan dan Pengambilalihan Bagi Pelaku Bisnis}

Dari sudut pandang pelaku bisnis, penggabungan, peleburan, dan pengambilalihan adalah perangkat strategi manajemen untuk dapat mencapai tingkat efisiensi yang lebih baik dengan memanfaatkan sinergi dan peluang pertumbuhan.

Beberapa manfaat yang dapat diperoleh oleh pelaku bisnis dari penggabungan, peleburan dan pengambilalihan adalah:

- Pembangunan infrastruktur lebih convenient karena skala ekonomi yang lebih baik,
- Penggabungan, peleburan, dan pengambilalihan pada kondisi tertentu menjadi pilihan yang lebih mudah daripada permohonan ijin,

- Keuntungan perluasan networking perusahaan dan jaringan,

- Memperoleh brand value,

- Keuntungan perluasan basis pelanggan/koporasi yang lebih besar,

- Produk dan layanan menjadi lebih beragam.

\section{Faktor Pendorong Penggabungan, Peleburan dan Pengambilalihan}

Faktor-faktor yang dapat mendorong dilaksanakannya penggabungan, peleburan, dan pengambilalihan sektor telekomunikasi diantaranya:

- Pertumbuhan investasi yang agresif, dukungan regulasi, tarif yang rendah serta menurunnya biaya jaringan dan handset,

- Kompetisi yang semakin ketat,

- Sinergi peluang untuk pertumbuhan bersama,

- Pengembangan teknologi telekomunikasi,

- Deregulasi industri dalam menyediakan layanan konvergensi,

- Dorongan untuk menciptakan nilai baru (produk inovatif).

\section{Gambaran dan Pola Penggabungan,} Peleburan dan Pengambilalihan di Industri Telekomunikasi

Penggabungan, peleburan dan pengambilalihan di industri telekomunikasi biasanya dipahami secara sebagai berikut:

- Bentuk penggabungan, peleburan, dan pengambilalihan sering diasosiasikan kepada perkawinan atau aliansi korporasi; 
- Penggabungan, peleburan, pengambilalihan diinisiasi dengan rencana akuisisi terhadap kompetitor dengan produk sejenis atau produk komplementer.

- Penggabungan, peleburan, pengambilalihan biasanya juga diinisiasi oleh perusahaan yang untung untuk mengakuisisi perusahaan yang merugi untuk membangun "tax shelter"

Sedangkan pola penggabungan, peleburan, dan pengambilalihan di bidang telekomunikasi dapat dilakukan dengan:

- Mengambilalih saham mayoritas satu perusahaan telekomunikasi dan membiarkannya tetap menjadi perusahaan stand alone tanpa merger dengan integrasi usaha. Pola seperti ini dilakukan pada akuisisi dengan resiko gagal merger yang tinggi,

- Akuisisi dan langsung dengan merger dengan persetujuan regulator terlebih dahulu,

- Pembelian aset perusahaan dan perusahaan tetap stand alone dengan integrasi usaha.

Akuisisi yang dapat dilakukan pada industri telekomunikasi, dapat dibedakan menjadi:

- Horisontal, yaitu akuisisi perusahaan dengan produk sejenis untuk dapat dengan cepat memperbesar cakupan layanan, basis pelanggan, tingkat profitabilitas dan skala ekomoni. Akuisisi horisontal juga dapat menciptakan efisien dalam pengembangan teknologi,

- Vertikal, yaitu akuisisi perusahaan dengan produk yang berbeda namun masih dalam stream layanan yang sama dalam rangka memperbesar economic of scope.

Secara lebih teknis, akuisisi yang terjadi pada industri telekomunikasi dapat dilakukan dengan beberapa pola, yaitu:
- Akuisisi perusahaan telekomunikasi berdasarkan ijin yang dimiliki atau cakupan area layanan,

- Akuisisi pita spektrum frekuensi yang dimiliki,

- Akuisisi infrastruktur dan jaringan telekomunikasi,

- Akuisisi pelanggan agar memperoleh basis ekonomi,

- Akuisisi perusahaan dengan EBITDA margin yang lebih tinggi, atau

- kombinasi dari pola akuisisi di atas.

Sebagai contoh penggabungan, peleburan, dan pengambilalihan di industri telekomunikasi, baik di Indonesia dan di negara lain:

- Merger Indosat dengan Satelindo

- Akuisisi Smart Telecom terhadap Mobile-8

- Pengambilalihan Mobillink Telecom oleh Broadcom

- Pengambilalihan BellSouth oleh AT\&T Inc.

- Akuisisi eScription Inc. oleh Nuance Communications Inc.

- Pengambilalihan Hutchison Essar oleh the Vodafone Group

- Pengambilalihan China International Telecommunication Construction Corporation oleh China Communications Services Corporation Ltd.

- Akuisisi Ameritech Corporation oleh SBC (Southwestern Bell Corporation) Communications

- Merger GTE (General Telephone and Electronics) dengan Bell Atlantic

- Akuisisi US West oleh Qwest Communications

- Merger MCI Communications Corporation dengan Worldcom 
Meskipun terdapat potensi adanya berdasarkan asas demokrasi dengan memperhatikan penggabungan, peleburan, dan pengambilalihan keseimbangan antara kepentingan pelaku usaha dan yang besar di sektor telekomunikasi, namun, kepentingan umum. Pengaturan tentang berdasarkan hasil diskusi dengan Telkom, diperoleh penggabungan, peleburan, dan pengambilalihan informasi adanya kendala dalam proses kesepakatan tersebut selanjutnya diatur dalam Peraturan penggabungan, peleburan, dan pengambilalihan. Pemerintah No. 57 Tahun 2010 (PP 57/2010).

Kendala tersebut biasanya adalah mengenai negosiasi B to B dalam menentukan kesepakatan biaya atau nilai transaksi. Dan juga kesepakatan mengenai nama yang muncul setelah dilakukannya peleburan.

Berdasarkan informasi yang diperoleh dalam FGD I, adanya potensi yang besar dalam pelaksanaan penggabungan, peleburan, dan pengambilalihan perlu dibarengi dengan kehatihatian. Hal-hal yang nantinya perlu diperhatikan adalah (Sutadi, 2014):

- Penguasaan sumber daya yang terbatas yang berkaitan dengan penomoran dan spektrum frekuensi;

- Penguasaan pasar baik praktik monopoli maupun oligopoli, serta penguasaan dari hulu sampai hilir akibat adanya integrasi vertikal yang dapat menimbulkan persaingan usaha tidak sehat;

- Potensi adanya diskriminasi interkoneksi;

- Potensi adanya transfer pricing maupun kartel.

8. Pengaturan Persaingan Usaha Tentang Penggabungan, Peleburan Dan Pengambilalihan Di Indonesia

Persaingan Usaha diatur dalam UndangUndang No. 5 Tahun 1999 tentang Larangan Praktik Monopoli dan Persaingan Usaha Tidak Sehat (UU No. 5/1999). Dalam Pasal 2 UU No. 5/1999 diatur tentang asas dan tujuan undangundang, yaitu bahwa kegiatan usaha di Indonesia Dalam perspektif hukum persaingan usaha, penggabungan, peleburan dan pengambilalihan dapat mengakibatkan konsentrasi pengendalian atau beralihnya pengendalian kepada satu pelaku usaha atau suatu kelompok pelaku usaha. Hal tersebut dapat mengakibatkan konsentrasi pengendalian atau konsentrasi pasar yang harus diawasi oleh KPPU.

Bentuk-bentuk penggabungan, peleburan dan pengambilalihan yang menjadi perhatian persaingan usaha adalah penggabungan, peleburan dan pengambilalihan sesuai PP 57/2010, yang cakupannya diperluas dalam Peraturan KPPU No. 3/2013 tentang Pedoman Penggabungan, Peleburan, dan Pengambilalihan Saham Perusahaan yang dapat mengakibatkan terjadinya Praktik Monopoli dan Persaingan Usaha Tidak Sehat.

Pemerintah telah menyiapkan rancangan kebijakan dan regulasi untuk mengatur pelaksanaan penggabungan, peleburan, dan pengambilalihan. Kebijakan dan regulasi tersebut meliputi penilaian terhadap pengabungan, peleburan, dan pengambilalihan di industri telekomunikasi, panduan pelaksanaan penggabungan, peleburan, dan pengambilalihan bagi penyelenggara telekomunikasi, bagi perusahaan yang terkait dengan partisipasi asing, bagi perusahaan telekomunikasi yang berstatus terbuka (Tbk), dan panduan bagi perusahaan telekomunikasi pada umumnya.

$$
\text { Penilaian terhadap penggabungan, }
$$
peleburan, dan pengambilalihan di industri 
telekomunikasi meliputi:

- Nilai perusahaan

Penilaian akan melihat:

- EV/EBITDA Ratio: pengembalian investasi dari akuisisi

- EV/Revenue Ratio: pencapaian rate of return dari akuisisi

- per subscriber EV (EV/number of acquired subscribers): nilai subscriber yang diakuisisi

- Penilaian kelayakan akuisisi, meliputi:

- Strategic and Business due diligence

- Technological \& Integration issues

- Financial \& commercial due diligence

Panduan pelaksanaan penggabungan, peleburan, pengambilalihan bagi penyelenggara telekomunikasi mencakup isu-isu mengenai:

- Persetujuan dari regulator diperlukan untuk penggabungan lisensi.

- Persetujuan regulator biasanya akan diberikan dalam jangka waktu sekitar empat minggu dari tanggal pengajuan permohonan.

- Penggabungan izin harus dibatasi pada area layanan yang sama untuk pasar yang sama.

- Jumlah minimal operator di daerah layanan untuk suatu layanan harus konsekuen setelah merger.

- Merger akuisisi atau restrukturisasi yang mengarah ke situasi pasar monopoli di bidang area layanan tertentu tidak diizinkan.

- Atas konsekuensi penggabungan lisensi, perusahaan gabungan berhak untuk jumlah spektrum yang dimiliki oleh entitas penggabungan, dengan syarat bahwa setelah merger, jumlah spektrum tidak akan melebihi jumlah bandwith tertentu per operator.
- Dalam hal perusahaan gabungan menjadi memiliki "Significant Market Power" (SMP) pasca merger, maka aturan yang masih ada dan peraturan yang berlaku untuk SMP juga akan berlaku untuk perusahaan gabungan.

- Proses penggabungan tidak dapat dijadikan alasan untuk mengubah kewajiban pajak dan lainnya.

Sedangkan panduan pelaksanaan penggabungan, peleburan, dan pengambilalihan terkait partisipasi asing meliputi:

- Jumlah kepemilikan asing pada gabungan perusahaan mengikuti ketentuan yang berlaku,

- Penyelenggara yang akan bergabung diminta untuk mengungkapkan status kepemilikan asing dan menyatakan bawa investasi asing adalah dalam batas maksimum per semester,

- Memenuhi aturan SDM asing pada level direksi dan manajerial tertentu.

Untuk perusahaan telekomunikasi yang berstatus terbuka (Tbk) berlaku ketentuan panduan pelaksanaan penggabungan, pengambilalihan dibawah ini:

- Menyertakan analisis dampak negatif terhadap perusahaan pengakuisisi atau perusahaan gabungan dari "appraisal independen”, karena dampak negatif dapat mengakibatkan "default" yang mengganggu operasional perusahaan dan dapat berdampak pada kelangsungan layanan kepada pengguna.

- Formulasi kerangka kerja analisis dampak negatif disusun regulator dengan mempertimbangkan aturan yang ada.

$$
\text { Sedangkan panduan pelaksanaan }
$$
penggabungan, peleburan, pengambilalihan pada perusahaan telekomunikasi mencakup berbagai laporan dan kewajiban yang harus dilakukan 
perusahaan setelah penggabungan, peleburan, dan pengambilalihan (post regulation). Laporan dan kewajiban tersebut terkait dengan:

- Laporan per semester dalam pencapaian komitmen penyelenggaraan setelah penggabungan, peleburan, pengambilalihan,

- Laporan kinerja penyelenggaraan per semester,

- Laporan dampak negative terhadap perusahaan bagi perusahaan terbuka per semester,

- Laporan susunan direksi dan manajerial tertentu setelah penggabungan, peleburan, dan pengambilalihan,

- Kewajiban yang terkait mencegah distorsi pasar akibat penggabungan, peleburan dan pengambilalihan (tergantung pada kondisi terjadinya penggabungan, peleburan, dan pengambilalihan) dan telah ditetapkan dalam persetujuan penggabungan, peleburan, dan pengambilalihan,

- Kewajiban SMP apabila setelah penggabungan, peleburan, dan pengambilalihan menjadi SMP.

Dari berbagai data dan informasi di atas, maka dapat dilihat bahwa pemerintah telah menyiapkan berbagai bentuk strategi, baik yang berkaitan dengan teknis teknologi jaringan dan layanan jasa telekomunikasi, maupun kebijakan dan regulasi mengenai penggabungan, peleburan, dan pengambilalihan yang mendorong tercapainya perbaikan-perbaikan di sektor telekomunikasi masa depan.

\section{IMPLEMENTASI}

Karena yang jadi kewenangan Kominfo hanya UU No. 36 Tahun 1999, disarankan agar Satuan Kerja yang berkewenangan, dalam hal ini
Direktorat Penyelenggaraan Pos dan Informatika serta Direktorat Sumber Daya Perangkat Pos dan Informatika dapat lebih mengoptimalkan penggunaan Undang-undang ini. Alat yang dapat dipakai terutama adalah regulasi terkait kualitas layanan sehingga operator yang tidak sanggup memenuhi regulasi ini karena kekurangan modal atau tidak ekonomis karena bisnisnya terlalu kecil akan mengkonsolidasikan usahanya.

Pada prinsipnya disarankan agar Satker terkait dapat mengetatkan "Law Enforcement" sesuai regulasi yang sah ada saat ini. Perlu diperhatikan bahwa pengetatan regulasi ini dapat mengakibatkan berbagai hal selain konsolidasi usaha yang dituju, misalnya pengaruh terhadap tarif, dsb. Karena itu perlu Regulatory Impact Analysis dilaksanakan sebelumnya.

\section{REKOMENDASI}

Dalam evaluasi penggabungan, peleburan, dan pengambilalihan, perlu mempertimbangkan beberapa aspek meliputi:

- Penciptaan struktur industri telekomunikasi yang sehat

- Peciptaan bisnis industri telekomunikasi yang sehat

- Pertimbangan teknis, antara lain kecocokan teknologi, sumber daya terbatas.

- Pemeriksaan legal: hukum perusahaan, pasar modal, penanaman modal

- Pendapatan negara

- Manfaat bagi kepentingan umum, contohnya inovasi teknologi

- Aspek lainnya

Perlu adanya pengaturan tentang keputusan atas permohonan penggabungan, peleburan, pengambilalihan, termasuk didalamnya 
persyaratan penggabungan, peleburan dan pengambilalihan yang harus dipenuhi. Pembagian peran dalam evaluasi penggabungan, peleburan, dan pengambilalihan suatu Perseroan dilakukan oleh masing-masing instansi terkait sesuai dengan kewenangan yang diberikan oleh Undang-Undang.

\section{PENUTUP}

Berdasar hasil studi ini dapat disimpulkan bahwa kondisi pasar seluler saat ini terdiri dari 7 pelaku usaha: 3 pelaku dominan, sedangkan sisanya non dominan dengan perilaku pasar perang harga dan kartel. Hal ini mengakibatkan menurunnya kualitas layanan, EBITDA margin penyelenggara menurun, bahkan negatif pada penyelenggara non dominan.

Sementara, untuk kondisi pasar seluler Indonesia ke depan dengan adanya penggabungan, peleburan, dan pengambilalihan, terdapat potensi perilaku anti persaingan karena jumlah pelaku usaha yang semakin sedikit. Di samping itu juga menumbuhkan potensi efisiensi dan efektifitas industri. Peningkatan keterjangkauan layanan dan distribusi, dan ketersediaan infrastruktur jaringan telekomunikasi serta terbentuknya komunikasi berbasis digital dan bisnis digital.

Oleh karena itu, regulator perlu berperan sebagai booster dan enabler dalam mekanisme penggabungan, peleburan, dan pengambilalihan industri telekomunikasi kedepannya.

Kebijakan dan regulasi penggabungan, peleburan dan pengambilalihan sektor telekomunikasi perlu memperhatikan aspek teknis, aspek perusahaan, aspek penanaman modal dan aspek persaingan usaha.

\section{UCAPAN TERIMA KASIH}

Terima kasih penulis sampaikan ke semua pihak yang telah ikut mendukung dan membantu terlaksananya penelitian ini, terutama kepada segenap pimpinan di Pusat Litbang Penyelenggaraan Pos dan Informatika yang telah memberikan kesempatan untuk melakukan penelitian ini.

\section{DAFTAR PUSTAKA}

Direktorat Telekomunikasi, Ditjen PPI. (2014). Paparan FGD I Kajian Konsolidasi Industri Telekomunikasi di Indonesia. Jakarta.

Jean-Christophe Lebraud, P. K. (2012). The Future of $M \& A$ in Telecom. McKinsey\&Company.

Kementerian Komunikasi dan Informatika. (2013). Buku Putih Kominfo Tahun 2013. Jakarta.

Puslitbang SDPPI. (2013). Studi Potensi Pasar Sekunder Spektrum Frekuensi Radio di Indonesia. Jakarta.

Peraturan KPPU No. 3/2013 tentang Pedoman Penggabungan, Peleburan, dan Pengambilalihan Saham Perusahaan

Peraturan Pemerintah No. 57 Tahun 2010 tentang Penggabungan atau Peleburan Badan Usaha dan Pengambilalihan Saham Perusahaan yang Dapat Mengakibatkan Terjadinya Praktik Monopoli dan Persaingan Usaha Tidak Sehat

Sutadi, H. (2014). Paparan FGD I Kajian Konsolidasi Industri Telekomunikasi di Indonesia. Jakarta.

Sutjipto, R. (2014). Peran Strategis Industri Telekomunikasi Dalam Mendukung Pertumbuhan Ekonomi Indonesia, "Dari Telkom Indonesia Untuk Indonesia". Makassar: PT Telkom Indonesia. 
Undang-Undang No. 36 Tahun 1999 Tentang Undang-Undang No. 5 Tahun 1999 tentang Telekomunikasi

Larangan Praktik Monopoli dan Persaingan

Usaha Tidak Sehat 